\title{
Institutions and bank behavior *
}

\author{
Rainer Haselmann ${ }^{\dagger}$ and Paul Wachtel ${ }^{\ddagger}$
}

May $20^{t h}, 2007$

\begin{abstract}
This paper explores how the legal environment affects bank behavior in 20 transition economies. Based on a newly constructed data set we find that banks' loan portfolio composition depends on the legal environment. If banks operate in a well-functioning legal environment they lend relatively more to SMEs and provide more mortgages. On the other hand, banks lend more to large enterprises and to the government if the legal system is unsound. As a transmission channel we identify the banks' willingness to accept collateral which depends on the bankers' perceptions of the prevailing laws regarding collateral.
\end{abstract}

JEL Codes: F34, F37, G21, G28, G33, K39.

Keywords: law and finance, bank lending, loan portfolio, collateral;

${ }^{*}$ We would like to thank the seminar participants at the CEPR/EBRD Tokyo Conference April 2006, the 12th Dubrovnik Economic Conference June 2006 and the $10^{\text {th }}$ Conference of the Swiss Society for Financial Market Research 2007 for comments on preliminary versions of this paper. Corresponding author: Paul Wachtel, Stern School of Business, New York, University, 44 West 4th Street, New York, NY 10012, USA; pwachtel@stern.nyu.edu

${ }^{\dagger}$ University of Mainz and Chazen visiting scholar, Columbia Business School, Graduate School of Business; rainer.haselmann@uni-mainz.de

†Professor of Economics, New York University, Stern School of Business 


\section{Introduction}

The link between the legal system and credit market development has been the subject of considerable interest. In their original papers La Porta, Lopez-de-Silanes, Shleifer, and Vishny $(1997,1998)$ and more recently Djankov, McLiesh, and Shleifer (forthcoming) show that the size of credit markets depend on the legal origin as well as the prevailing creditor rights in a country. On a micro level, Haselmann, Vig, and Pistor (2006) find that banks expand their credit supply once legal rights improve. These papers, however, say little about how the legal environment affects the size and composition of capital market activity. For example, how do differences in the legal system influence a banker's lending decision? Do creditors simply lend more to the same customers if they operate in a better institutional setting, or do they lend to new types of customers? Under what circumstances are creditors willing to take risk and engage in lending under asymmetric information? In order to answer these questions, we need detailed information on the loan portfolio of creditors that operate in different institutional settings.

In this paper we show that differences in the legal system influence the loan portfolios of banks with data from a new survey of bankers from the transition countries. Prior work has been unable to relate loan composition to cross country differences in the legal environment because information on the banks' borrowers has not been available. Such information is generally not on financial statements that are commonly used in cross country credit market development studies. Although detailed bank portfolio data are available for some developed countries such as the U.S., consistent information on bank behavior and the banking environment from many countries is difficult to obtain. In this paper we utilize data from a 2005 EBRD survey, the Banking Environment and Performance Survey (BEPS). By 
conducting more than 200 face-to-face interviews with leading bank managers in 20 transition economies, information on banks' loan portfolios as well as the bankers' perceptions was obtained. ${ }^{1}$ An additional novelty of this study is that we distinguish between the influence of the bankers' perceptions of their legal environment and the influence of objective measures of the quality of the legal system.

The paper offers three findings: First, differences in the legal environment are an important determinant of the composition of bank loan portfolios. Better legal systems are associated with less lending to low asymmetric information customers such as large and government-owned enterprises. Similarly, when bankers have positive perceptions of the legal environment, there tends to be relatively more lending to information opaque borrowers such as SMEs and mortgage borrowers. Consequently, a better legal environment does not only foster a bigger credit market as established in aggregate cross country studies (the 'law and finance' literature cited above), but also shifts the composition of lending towards private sector capital formation.

Second, we identify collateral as the main trigger for creditors to lend to information opaque entities. The willingness to accept collateral depends on the actual legal system, as well as the banker's perception of the legal environment. Once lenders accept different types of assets as collateral, they are more willing to engage in lending that involves considerable asymmetric information.

Finally, we find that not only the actual quality of the legal system influences bank behavior, but also the individual banker's perceptions of the law. Thus, even after controlling

\footnotetext{
${ }^{1}$ The transition economies provide an ideal laboratory for examining the effects of the legal environment on bankers' lending decisions because progress towards a market economy has resulted in wide variation in the performance and functions of banks in the countries in our data. This is especially true for creditor rights as pointed out by Pistor (2000).
} 
for country heterogeneity we find that bankers' perceptions influences their lending decisions. Therefore policies to encourage capital formation should not only address the laws enacted, but also develop confidence in the operation of the legal system.

The paper is structured as follows. Section 2 motivates the link between creditor rights and the portfolio decision of banks and develops the hypotheses tested. In section 3 , the banking survey and descriptive statistics are presented. The empirical analysis is provided in section 4 and section 5 concludes.

\section{Motivation and Hypotheses}

Our paper builds on two strands of literature and fills a gap between them. First, we have already cited the law and finance literature which established the link between the quality of the legal environment and aggregate capital market development. The main conclusion from this literature is that better legal systems and institutions seem to cause better outcomes for financial markets. Second, the corporate finance literature has demonstrated the link between institutional environment and the capital structure of firms (e.g. Booth et al. 2001, Demirgüc-Kunt and Maksimovic 1998, 1999). However, there has heretofore been little work on how the banks themselves are affected.

There are, of course, similarities between the influence of the legal environment on firms and on banks. According to Demirgüc-Kunt and Maksimovic $(1998,1999)$ a higher proportion of firms use long-term external financing in countries with a better legal system. In a related study, Fan, Titman, and Twite (2006) argue that firms operating within legal systems that provide better protection for financial claimants tend to have more long-term 
debt as a proportion of total debt. Giannetti (2003) finds that in countries with good legal protections, it is easier for small firms investing in intangible assets to obtain loans. Furthermore, she shows that firms operating in countries that favor creditor rights are associated with higher leverage and greater availability of long-term debt. Braun (2003) underlines the importance of tangible assets for lending in poorly developed capital markets. He shows that industries with fewer tangible assets grow relatively slowly in countries with poorly developed financial systems. ${ }^{2}$

In our first hypotheses we relate bankers' use of collateral to bankers' perception of their environment. The importance of collateral in bank lending was established by Bester (1985), Besanko and Thakor (1987) and Boot and Thakor (1994). They showed that collateral can be an instrument to overcome the asymmetric information problem between lender and borrower. ${ }^{3}$ In their framework, collateral serves as a signaling device that offers the lender a signal about the true riskiness of the borrower.

According to the incomplete contracting literature (e.g. Hart and Moore 1994, 1998), the terms of a credit contract depend on the bargaining power of the creditor to force repayment. The ability to pledge collateral in case of default is such a mechanism through which lenders control borrowers. Thus, the institutional environment (e.g. collateral laws) is a determinant of creditors ability to force repayment. In accordance to this argument, Davydenko and Franks (2004) find that in countries with creditor unfriendly codes banks

\footnotetext{
${ }^{2} \mathrm{~A}$ strengthening of credit rights may, however, not also be associated with a higher availability of external finance. Vig (2006) shows for Indian firms that improvement in the rights of secured creditors leads to a reduction in total debt.

${ }^{3}$ The asymmetric information problems means that only the borrower knows the true riskiness of a project to be financed (Akerlof 1970). The more difficult it is for the lender to gather information about the project, the more pronounced is the asymmetric information problem. More recently, Dell' Ariccia and Marquez (2004) have shown that the greater the information asymmetries between bank and borrower, the higher the interest rate charged by the bank.
} 
recovery rates must be lower. If lenders anticipate this, they adjust their contract terms by requiring more collateral. The latter suggest a negative link between creditor rights and the demand for collateral.

Nevertheless, these arguments are based on developed countries. In our sample countries, institutional uncertainties are generally higher so that it is not clear whether a bank is able to collect its collateral at all in case of default. The use of collateral in lending arrangements relies on the existence of an appropriate legal framework and a well functioning court system. Djankov, Hart, McLiesh, and Shleifer (2006) show that the efficacy of debt enforcement depends on the legal origin of a country as well as structural aspects of debt contracts and appeals. Empirically, Qian and Strahan (2005) find that in countries with better creditor rights, more loans are secured. The use of collateralized loans makes sense if, in case of default, the legal system allows the lender to obtain possession of the collateral. Furthermore, a legal system needs to provide the means to register the collateral when a loan is made in order to prevent borrowers from pledging the same asset more than once. In our sample countries these issues seem to be of importance to bankers. Therefore, we think that a good legal system is a prerequisite for a banker to be willing to accept collateral in a lending arrangement. Note that this notion is different from the incomplete contracting approach where collateral serves as a device to substitute for an efficient bankruptcy code. Since we have information on the acceptance of assets as collateral by the banks, we can test the relationships directly. To begin, there is a positive link between the legal system and the willingness to accept collateral: 


\section{Hypothesis 1 (H1): If the laws on securing collateral are more reliable, then banks will be more willing to accept collateral in lending. ${ }^{4}$}

Next, we note that the degree of asymmetric information between lender and borrower varies considerably with different types of borrowers. In the case of government lending the asymmetric information problem is negligible, since the government can always print money to avoid default. At the other extreme is lending to new firms or small firms that have no credit history which makes it difficult for a bank to assess credit risk. Therefore, the ability to take collateral is especially important for credit contracts with such borrowers. That is, the higher the degree of asymmetric information between lender and borrower, the more important is the ability to rely on collateral (see Liberti and Mian 2005). The willingness to collateralize loans, however, depends on the quality and enforceability of the legal system. Thus, a legal environment that reliably enables the lender to take collateral should have more loans to information opaque borrowers. This leads us to our second hypothesis:

\section{Hypothesis 2 (H2): The quality of the legal system and the proportion of a bank's loans made to information opaque borrowers are positively correlated. 5}

Banks find it considerably more difficult to gather information about solvency of a small enterprise compared to a large enterprise. Large enterprises are more likely to be publicly held and therefore obliged to provide audited financial statements. If they are also publicly traded, the stock markets provide a monitoring function. In contrast, for small enterprises, banks generally have to rely on unaudited financial information and their subjective judgment of the project to be financed. Thus, asymmetric information problems

\footnotetext{
${ }^{4}$ Laws regarding collateral generally distinguish between immovable assets (usually land or real estate) and movable assets (e.g. machinery, cars, etc.) to be pledged as collateral (Pistor 2000). The BEPS survey makes this distinction as well so we can test the hypothesis for each type of collateral separately.

${ }^{5} \mathrm{By}$ the quality of the legal system we mean both the laws related to banking transactions and how well they are applied.
} 
loom larger in SME lending and, as Berger and Udell (1995) pointed out, collateral is very important in lending to SMEs. Similarly, Menkhoff et al. (2006) find for a sample of Thai banks that collaterization is more important for loan contracts with SMEs. As argued before (H1), the willingness to use collateral depends on the legal system. If the legal system is, however, not sufficiently good to allow for loans secured by collateral, banks prefer to lend to customers about whom they can easily obtain information. Large enterprises are clearly such customers.

Mortgage lending is virtually defined by the existence of collateral that can be taken to secure the loan. However, the law has to provide the legal context for acquiring properties when a mortgage is in default. This is not a simple matter particularly for occupied residential properties. However, once the law defines the collateral relationship and there is confidence that it can be applied, than mortgage lending should flourish.

Consumer finance usually involves either credit card debt or the purchase of movable assets. Credit card debt is generally not collateralized and therefore should be independent of differences in the legal system. Movable assets on the other hand might be used as collateral. However, the costs of liquidating such collateral can be substantial and banks are likely to use other means of reducing the risks of consumer finance. Collateral laws are more likely to be important in SME and mortgage lending and so the proportion of loans made to consumers may or may not be related to the quality of collateral laws.

Finally, information asymmetries are unlikely to play an important role for government lending, since state guarantees are generally the most secure claims in an economy. The government's ability to tax makes its borrowing riskless. Thus, banks do not need to gather information or monitor performance when the government is the borrower. When the 
legal environment makes interactions with private sector borrowers problematic, banks may prefer to lend to the government and other state entities.

The relationships suggested by this discussion between the overall quality of the legal environment and bank lending are summarized as follows:

\begin{tabular}{cccccc}
\hline & SMEs & $\begin{array}{c}\text { Large } \\
\text { enterprises }\end{array}$ & Mortgages & $\begin{array}{c}\text { Consumer } \\
\text { lending }\end{array}$ & Government \\
\hline Quality of law & + & - & + & $?$ & - \\
\hline
\end{tabular}

\section{The survey data and descriptive statistics}

\subsection{Loan data}

The BEPS sample design was based on a random sample of 423 banks from 20 countries. Banks in smaller countries and also in Russia (26\% of the sample frame) were over sampled. More than half the banks (63\% when Russia is excluded) agreed to participate and data were collected from face-to-face interview with 219 high ranking bank managers. With Russia excluded the response rate was $63 \% .{ }^{6}$ Each bank was linked to the Bank Scope data after a careful examination to make sure that the correct Bank Scope data was used. That is, care was taken to make sure that the Bank Scope data used had the proper bank identification and level of consolidation. ${ }^{7}$ When the Bank Scope data for the 423 banks in the EBRD sample frame are compared to the data for the 219 banks that responded to the survey, there is no

\footnotetext{
${ }^{6}$ The countries with the lowest response rates were, in addition to Russia, the Ukraine and also Hungary and the Czech Republic. Successful bankers in the advanced transition countries might have been less inclined to set aside the time for an EBRD interview than others. In the tense environment in Russia and the Ukraine bankers might have had other reasons to avoid responding.

${ }^{7}$ The Bank Scope data set was prepared by Dr. Anita Taci of the EBRD.
} 
indication of systematic response bias. ${ }^{8}$ The actual sample sizes in the empirical analysis is often smaller because Bank Scope does not cover a handful of banks that responded to the survey and, more importantly, responses for some questions are missing for many banks. ${ }^{9}$ As noted earlier, the BEPS survey asked the bank manager to provide an allocation of customer loans among different types. ${ }^{10} \mathrm{We}$ are able to use these responses to construct the loan proportions according to the following borrower types:

- Small and medium enterprises (1 to 249 employees),

- Large enterprises (250 or more employees),

- Mortgages,

- Consumer finance,

- Lending to the government and state-owned enterprises, and

- Other lending.

The survey also provided information on bank ownership. We used a majority ownership basis for classifying banks as government or foreign owned. Only $9 \%$ of the banks were government owned at the time of the survey. ${ }^{11}$ In fact the privatization process was largely completed in all of the transition countries. Even banks that reverted to government ownership during banking crises in the late 1990s (e.g. in Romania and Croatia) had been privatized when the survey was conducted in 2005 . Fully $61 \%$ of the respondent banks are

\footnotetext{
${ }^{8}$ In most countries the average asset level and the return on assets are about the same for responding and non-responding banks. The correlation of the country average ROAs from full sample and from the survey respondents is 0.97 and the rank correlation is 0.76 .

${ }^{9}$ The survey design included all banks in the country which might include some institutions which are not picked up by Bank Scope. There were 17 respondent banks excluded because there was not adequate Bank Scope data for 2004 in Moldova, 3 in Macedonia, 3 in Belarus, 2 in Slovakia and 1 in each of Bosnia, Bulgaria, Poland, Serbia, and Ukraine. One additional Serbian bank is eliminated because of inconsistencies in the Bank Scope data.

${ }^{10}$ The questionnaire is available form the authors upon request.

${ }^{11}$ The state owned banks including two for which there is no Bank Scope information were concentrated in a few countries, 3 each in Belarus, Bosnia and Serbia and 2 in the Czech Republic and one in each of 7 other countries.
} 
foreign. The foreign banks include both greenfield banks and banks acquired by mergers and acquisitions. Definitions of all varibales are summarized in Table I.

Table II shows summary statistics for the lending ratios for all respondent banks and then divides the banks by ownership, region and size. The row totals do not add to 100 because other lending is not shown and also because the sample sizes used to calculate the means often differ due to non responses.

Perhaps the most striking observation from Table II is that foreign banks do less lending to SMEs than either government or domestic private banks. One explanation for this is that foreign banks generally have to overcome cultural barriers and therefore bear higher information costs than their domestic counterparts (Buch 2003). These barriers may be formidable when it comes to information gathering about opaque SMEs so foreign banks are much less likely than other banks to lend to small business (Stiglitz 2003, Sengupta forthcoming, Mian 2006, Berger et al. 2001). Giannetti and Ongena (2005) claim that foreign banks in a sample of transition countries lack the local information that is particularly important for lending in countries where asymmetric information problems are severe. ${ }^{12}$ Such local information is generally easier to collect for domestic banks through relationship banking (Berger and Udell 2002).

However, foreign banks are more active lenders to households, particularly for mortgages. The foreign banks may do more mortgage lending because the specific expertise regarding mortgage contracts can be transferred from the parent company. Lending to governments and government affiliates is only prominent among state owned banks. Differences

\footnotetext{
${ }^{12}$ However, they find that foreign bank entry is overall beneficial to a country. Moreover, Bonin et al. (2005) find that foreign banks in transition are more efficient and perform well.
} 
in mortgage lending tend to be country specific because not all the transition countries have defined mortgage contracts.

Since, the number of respondents from many countries is too small to make a comparison of averages by countries informative, we show the means for three country groups: the 8 transition countries that are now members of the European Union (EU), the countries of the former Soviet Union (FSU) with the exception of the Baltic countries which are already part of the EU, and the countries of South Eastern Europe (SEE) ${ }^{13}$ Mortgage lending is primarily found in the EU countries where the legal infrastructure for such loans is in place. Banks in the FSU do more corporate lending, perhaps because many of them are corporate affiliates or house banks although banks in the FSU do more lending to both large and small enterprises.

Finally, we group the banks into three size groups with roughly about a third of the banks in each group: Assets less than $\$ 200$ million, between $\$ 200$ million and \$1 billion and in excess of $\$ 1$ billion. Smaller banks do more SME lending, while larger banks prefer to lend to large enterprises. The latter observation has been stated in the current banking literature by Berger et al. (2001). Large banks do less corporate lending overall, in part because they are more active in household lending.

\footnotetext{
${ }^{13}$ The countries are:

EU: Czech Republic, Estonia, Hungary, Latvia, Lithuania, Poland, Slovakia, Slovenia;

FSU: Belarus, Kazakhstan, Moldova, Russia, Ukraine;

SEE: Albania, Bosnia, Bulgaria, Croatia, Macedonia, Romania, Serbia.
} 


\subsection{Acceptance of collateral}

The BEPS survey provides information about bankers' willingness to accept collateral. We construct measures of the frequency with which banks accept immovable assets as collateral and another variable for the frequency of acceptance of movable assets.

The survey asks bankers how frequently they accept different types of assets as collateral on a scale of 1 (Never) to 6 (Always). ${ }^{14}$ The responses for the different asset types were averaged so the overall indicator ranges from 1 to 6 for both movable and immovable assets. These indicator scores provide an ordinal ranking rather than an objective numerical measure of intensity. For this reason we create dummy variables that separate responses into high (scores from 4 to 6 ) and low (scores from 1 to 3 ) groups for the acceptance of collateral measures. Specifically the dummy variables for the "Acceptance of (im)movable assets" takes the value of one if a bank accepts (im)movable assets frequently as collateral and zero otherwise.

\subsection{Objective measures for the legal environment}

The law and finance literature measures the quality of the legal or banking environment with national indicators. We follow in this tradition with measures of the quality of the banking environment constructed from EBRD information. In addition, we also utilize information concerning the individual bankers' perceptions of the environment from the BEPS survey. Thus, two types of legal indicators are examined in this paper. The first, described in this section, are objective measures of the legal environment for banking. The second type

\footnotetext{
${ }^{14}$ The survey asset categories land and buildings were classified as immovable assets. Movable assets include vehicles, other tangible movable property (e.g., business equipment) and inventory (stocks of goods to be sold).
} 
reflects the bank managers' assessment of the legal environment which are described in the next section.

Our national measures of the banking environment are based on data collected by the 2004 EBRD Legal Transition Programme (LTP). ${ }^{15}$ Two country specific objective measures of the banking legal environment are constructed from LTP.

The first indicator measures how well a lender's claim can be enforced (referred to as LTP - Enforcement of law). It is based on three EBRD indices, each with a score that ranges from 0 to 10 :

(i) the amount that can be expected to be recovered from a debtor,

(ii) the time needed to realize recovery, and

(iii) the simplicity of the legal process to be followed.

Our indicator, LTP - Enforcement of law, is the sum which ranges between 0 and 30 .

As before, the sum of the scores does not have any meaning that would justify its use as a continuous variable. It provides an ordinal ranking rather than some objective numerical measure of intensity. Therefore, we additionally rank the countries by the scores and create a dummy variable that reflects whether a country has a high or low quality of law enforcement score. This indicator is referred to as LTP - Enforcement of law (dum) and it has a value of one for countries with a high quality of law enforcement score. ${ }^{16}$

The second measure is an index of the quality of collateral law, referred to as LTP Quality of law. It is based on six criteria concerning the legal regime for secured trans-

\footnotetext{
${ }^{15}$ See EBRD Legal Survey (2004) for further details.

${ }^{16} \mathrm{We}$ compared results with different that used 25,50 or 75 th percentile of the sum as the cut off point for the dummy variable. The regression results shown below uses the dummy based on the 75th percentile cut-off which performs best.
} 
actions, which are shown in Appendix A. EBRD gives a country a score ranging from 0 to 3 on each criterion and the overall measure is the sum of the scores. Consequently our LTP - Quality of law indicator ranges from 0 to 18 . For the same reasons mentioned above, we also construct a dummy measure that separates countries into groups with high and low quality of law (LTP - Quality of law [dum]).

The LTP indicators are country specific. However, the grouping of countries by the quality of the banking environment does not correspond with a simple separation between advanced transition countries and the others. For example, for both variables, Albania is in the high quality banking environment group and Poland is in the low quality banking environment.

\subsection{Bankers' perceptions of the environment}

The BEPS survey asked bank managers about their perceptions of law enforcement and of the quality of collateral laws for both movable and immovable assets. In each instance, the bank manager was given several relevant criteria and asked to provide a response on a six point scale. In order to synthesize the diffuse responses we follow Hoshi (2006) and aggregate the responses to construct indicators of positive views about law enforcement and collateral laws. Further, we divided each of the overall indicators into two groups reflecting high and low perceptions of the legal quality on each dimension.

The questions about perception of movable and immovable collateral law present four statements (the specific statements are in Appendix B) and ask the responding bank executive to indicate the extent of his or her agreement on a scale from 1 (strongly disagree) to 6 (strongly agree). We added the scores (using averages for missing responses) in order to 
get an overall indicator of respondents' confidence in the collateral laws. We then examined the distribution of the scores and divided the respondents into two groups reflecting high and low confidence in the collateral laws for both movable (BEPS - immovable assets perception) and fixed collateral separately (BEPS - movable assets perception).

A similar procedure was used to distinguish bankers with high and low confidence in the ability of the court system to resolve disputes. BEPS respondents were asked to express their agreement with five statements on a scale from 1 (never) to 6 (always); e.g. whether the system is fair and impartial, affordable, able to enforce decisions, etc. (the questions are shown in Appendix B). This indicator, which we refer to as BEPS - Court perceptions), ranges from 5 to 30 . As before, we also separate respondents into groups with high and low confidence in the court system to construct the dummy variable BEPS - Court perception (dum) which has a value of one for bankers with high confidence.

\subsection{Country controls and instruments}

In our empirical analysis we test a variety of country control variables to account for country heterogeneity. Data on the CPI inflation rate, GDP per capita, GDP per capita growth, the interest rate spread and the ration of private credit to GDP are taken from the World Bank Development Indicators. Several studies (Pagano and Jappelli 1993; Jappelli and Pagano 2002; Djankov et al. forthcoming) underlined the importance of information provision mechanisms as a determinant of credit supply. Therefore, we also test the 'Credit information index' from the World Bank 'Doing Business' survey that measures rules affecting the scope, access, and quality of credit information in each country. Finally, we tested Fitch's sovereign debt ratings which we refer to as the 'Country risk rating'. 
In the later analysis we use the bankers' perceptions of the institutional characteristics as an explanatory variable. Since these perception indicators might be endogenously related to the bankers' lending decisions we will instrument for institutional perception with measures of the actual contract and debt enforcement processes in each country. Unlike the other explanatory variables, these instruments are not affected by bank lending behavior. Thus, the instruments are correlated with bankers' perceptions but not with the residuals in the lending equations. Information on contract enforcement has been identified by Djankov et al. (2003) and collected by the World Bank 'Doing Business' survey. It provides us with three valid instruments for the banker's perceptions of the legal system. The first is 'Procedures' or the number of interactions mandated by law or regulation between the parties which consists of steps to file the case, steps for trial and judgment and steps necessary to enforce the judgment. The second, 'Time,' records the number of calendar days from the time the plaintiff files a lawsuit until payment is made. The third instrumental variable, 'Cost,' is the cost of enforcing a contract (including court costs and average attorney fees) as a percentage of the claim. An additional instrument is a measure of the 'Efficiency' of debt enforcement in each of our sample countries taken from Djankov et al. (2006). It is a constructed measure of the efficiency of debt enforcement based on local practitioner's evaluations of a hypothetical case of a debt default and insolvency. Definitions and summary statistics for our controls and instruments are summarized in Table I.

\subsection{Summary statistics}

The interrelationships among the five measures of the banking environment (the three BEPS perceptions measures and the two LTP objective or actual measures) are summarized in Ta- 
ble III which shows the correlations among the summed indicator scores. The correlations are generally not large. In particular, the correlations between the perceived quality measures and the actual quality measures are small, which indicates that both variables contain different information. One reason for this low correlation between actual and perception legal indicators might be that many bankers in countries with objectively poor quality of law (according to LTP - Quality of law) report a good perception of their legal environment. Overall we observe a higher within country variation of the BEPS perception responses in countries with a relative poor score in the LTP survey. This discussion underlines the importance of differentiating between actual law and its perception.

\section{Empirical Results}

\subsection{Acceptance of collateral}

Our hypothesis $\mathrm{H} 1$ implies that collateral is only effective as a tool to overcome asymmetric information in the borrower-lender relationship, if the legal environment is sufficiently good. That is, banks will only accept collateral, if they have a good perception of the law that protects collateral for the lender. The banker's choice to accept a certain type of collateral is examined with a probit model where the dependent variable has a value of one if the $\mathrm{i}$-th bank in the $\mathrm{j}$-th country accepts certain assets as collateral:

$$
\begin{aligned}
& \text { (Acceptance of (im)movable assets })_{i j}=\beta_{0}+\beta_{1} \cdot \log \left(\text { Asset }_{i j}\right)+ \\
& \beta_{2} \cdot \text { Ownership }_{i j}+\beta_{3} \cdot \text { Country Controls }_{j}+\beta_{4} \cdot \text { LEGAL }_{i j}+\varepsilon_{i j}
\end{aligned}
$$


We control for both the size and ownership in equation (1) and are particularly interested in the coefficient $\beta_{4}$ which measures the effect of the legal indicator on the willingness to accept collateral.

Probit estimates are shown in Table IV for immovable assets (columns 1 to 5) and movable assets (columns 6 to 10). Overall, there is some indication that larger banks and domestic banks (the omitted group) are more willing to use collateral. Both the quality of the law enforceability and the perception of collateral laws have a significant positive effect on a bank's acceptance of collateral. The results are robust; both the perception and the actual quality of the law are significant when they enter the probit model separately (columns 2,3 and 7,8 ) with the one exception of the enforcement of law on the acceptance of movable assets. In columns 1-3 and columns 6-8, the legal indicators are the summed responses. A robustness check is provided in columns 4-5 and 9-10 when the legal indicators are the dummy variables. Results are the same whether we use sum or dummy variable definitions of our legal indicators.

These probit estimates suffer from endogeneity bias since bankers' behavior is the dependent variable and the same bankers' perceptions of the environment appear as explanatory variables. However, clear support for our hypothesis is also found when the exogenous legal measure (LTP - Enforcement) is used by itself. All in all these results provide clear support for hypothesis H1. 
To provide some interpretation of the probit results, we calculate the marginal impact of the environmental variables on the probability of accepting collateral. Recall that the probit model for a binary outcome variable $Y$ is:

$$
\operatorname{Pr}(Y=1 \mid X=x)=\Phi\left(x^{\prime} \beta\right)
$$

where $\Phi$ is the cumulative distribution function of the standard normal distribution. Thus, an estimated coefficient, $\beta$, is not the marginal impact of a variable on the probability of accepting collateral. The marginal effects are easily calculated and some examples are presented in Table V. We show the estimated probability of collateral acceptance for a domestic bank that has mean asset size with different combinations of the legal indicators. For example, such a bank has a probability of about 81 percent of accepting immovable assets as collateral if its legal perception and environment are good. If the legal perception and environment are bad, the probability is only about 44 percent. The influence of the legal measures on the probability of collateral acceptance is of similar magnitude in other examples.

\subsection{Lending and the banking environment}

Our second hypothesis, H2, relates to the effect of the legal environment on a banker's decision to lend to certain types of borrowers. To test these relationships, we include the legal indicators in a system of equations for the composition of the banks' loan portfolio. The dependent variables are the percentages of total lending which sum to one and we also control for bank size, ownership and country specific characteristics. The simultaneous system is given by:

$$
(\text { Lending ratios })_{i j k}=\beta_{0 k}+\beta_{1 k} \log \left(\text { Assets }_{i j}\right)+\beta_{2 k} \text { Ownership }{ }_{i j}+
$$




$$
\beta_{3 k} \text { Country Controls }_{j}+\beta_{4 k} L E G A L_{i j}+\varepsilon_{i j k}
$$

where $i$ indexes banks, $j$ countries and $k$ the lending categories. ${ }^{17}$ Since the LTP indicators only vary by country, country fixed effects which would absorb the variation in the legal variables cannot be included. Instead, we include each country's GDP per capita and inflation rate to control for country heterogeneity.

The aim of this system is to examine the allocation of the lending portfolio among SME, large enterprise lending, mortgages, consumer finance, government lending and other loans. Since all categories add to 100 percent, other lending is explained by the other categories and is therefore left out of the estimation. We will estimate (3) first as a simultaneous system of seemingly unrelated regression (SUR, Zellner 1962) in order to account for cross equation error correlation. We will also present instrumental variable estimates to account for possible endogeneity of the perception variables.

The SUR estimates of (3) are shown in Table VI. The coefficients of the control variables are as expected. Enterprise lending is significantly related to bank size - negatively for SMEs and positively for large enterprises. Interestingly, the domestic private banks (the omitted ownership category) do more lending to enterprises, both SMEs and large enterprises while government banks lend more to the government. The inflation rate is negatively correlated to mortgage finance and positively to large enterprise lending while GDP per capita has little influence on the lending ratios.

The legal environment has a significant effect on the loan portfolio composition of banks. Bankers that have a better perception about their court system lend relatively more

\footnotetext{
${ }^{17}$ By construction, the lending ratios are bound between zero and one. Histograms of the loan ratios indicate that the underlying distributions are, however, symmetric.
} 
to SMEs and less to large enterprises. The higher the score on the LTP - Enforcement of law variable the less banks lend for consumer finance and the more for mortgage finance. Finally, better law enforcement is associated with less government lending. These results are entirely consistent with the earlier discussion of hypothesis $\mathrm{H} 2$.

Both the bankers' perceptions of the legal environment and the objective measures of a country's quality of law enforcement affect the portfolio allocations. Since the magnitudes of the two variables are similar (the mean of BEPS - Court perception is 16.96 and of LTP - Enforcement of law is 19.54) we can compare the coefficients. Bankers' perceptions are the dominant influence on enterprise lending, the shift towards SMEs and away from large enterprises. National quality of law is the more influential determinant of household and government lending.

The overall impact of the legal environment on lending ratios can be measured by considering one standard deviation increase in both legal environment variables. The effort of such an improvement on lending ratios is shown below (figures are based on specification (3) as reported in Table VI). Improvements in the legal environment are associated with important changes in lending patterns. There is a shift away from large enterprises and consumer lending and government and towards SMEs and mortgages.

\begin{tabular}{cccccc}
\hline SMEs & $\begin{array}{c}\text { Large } \\
\text { enterprises }\end{array}$ & $\begin{array}{c}\text { Consumer } \\
\text { lending }\end{array}$ & Mortgages & Government & Other \\
\hline $3.76 \%$ & $-5.36 \%$ & $-5.09 \%$ & $4.79 \%$ & $-2.26 \%$ & $4.16 \%$ \\
\hline
\end{tabular}

The use of perceptions to measure the quality of the legal environment might entail an endogeneity problem. Bankers that know that they lend more to information opaque borrowers might claim that they have more trust in the legal system in order to justify their lending 
decision. This endogeneity problem might cause an upward bias in the BEPS coefficients in Table VI (Engle et al. 1983). For this reason, we provide as an alternative instrumental variable estimates of the system (3). As discussed earlier we believe that measures for contract and debt enforceability are valid instruments for a bankers' perceptions regarding the court system because they should be correlated with bankers' perceptions but not with the portfolio allocations. The specific instruments used, in addition to the other independent variables, are the efficiency of debt enforcement, the average days it takes to enforce a contract and the number of procedures to enforce a contract through court (see Table I for definitions). Instrumental variable estimates of (3) are shown in Table VII.

The instrumental variable estimates are qualitatively the same as those shown with SUR estimates in Table VI except that the coefficients on the BEPS perception variable are larger. The overall effect of an improvement in the legal environment (i.e. a one standard deviation increase in both legal variables) has the same effect as before. However, with these results the predicted shift from large enterprise and consumer lending to SMEs and mortgages are larger.

In both Tables VI and VII, the legal variables are sums of responses to various questions or sums over several indicator variables. As noted earlier, these ordinal measures may not be appropriate as continuous variables in a regression analysis. Alternatively, we construct dummy variables that categorize each of the legal indicators into two groups. In Table VIII, we present a summary of estimates of system (3) that use the dummy indicators for the legal environment variables. Only a summary of the results is shown, the coefficients on the legal variables and the R-squared from both SUR and IV estimates. The SUR estimates with the dummy legal indicators can be compared to the SUR estimates in Table VI and the 
IV estimates to those in Table VII. If anything, the results are stronger with dummy legal variables. The R-squared shown in Table VIII are larger than in the corresponding equations in Tables VI and VII. When bankers' perceptions are in the top of the distribution there is substantially more SME lending and less large enterprise lending. The shift into mortgage lending and out of consumer and government lending by banks in countries with higher quality of law enforcement is significant but not as large as the impact on enterprise lending.

Summarizing, we find that the legal environment is an important determinant of the composition of the loan portfolio. We find that banks that operate in a better legal environment lend proportionally more to SMEs and give out more mortgages. Further, we find that in a good legal environment especially the proportion of lending to large enterprises, government and other household lending is lower.

\subsection{Robustness tests and further evidence}

In this section, we provide estimates of alternative specifications of the loan proportions model (3) in order to establish the robustness of our conclusions. To begin, we have, so far shown estimates with both the perceptions (BEPS) and objective (LTP) legal measures in our system. In Table IX we show the coefficients of these legal indicators when the LTP and BEPS measure enter the equation system separately. In the first two rows we enter the sum indicators and in the last two rows the dummy indicators in our basic specification. Including the indicators separately generally improves our results.

Additionally, there is a possibility that our legal indicators capture cross-country heterogeneity rather than differences in the legal environment. The basic specification included two country controls GDP per capita and inflation and in Table X we show estimates with 
additional controls - the interest rate spread, GDP growth rate, ratio of private credit to GDP, the country risk rating, the credit registry indicator as well as dummy variables for regions. ${ }^{18}$ The regional dummies enter the system significantly. There is proportionally less enterprise lending and more household lending in the EU countries. Higher GDP growth is correlated with lower government lending. The interest rate spread, size of the credit market, country risk ratings as well as the credit registry indicator are mostly unrelated to the loan portfolio composition of bankers. Most importantly, including these country controls in our system has hardly any effect on the size or significance of our legal indicators. These results strongly suggest that the legal indicators included in our system do not simply account for country heterogeneity but for the prevailing influence of differences in the legal environment banks operate in.

While the LTP measures only vary by country, the BEPS measures vary at the bank level. Thus, in equations which only include the BEPS measure we can completely control for cross-country heterogeneity by including country fixed effects. This is a considerable advantage over the original 'Law and Finance' literature, since countries that differ in their legal systems are likely to also differ in other dimensions that are difficult to account for. In Table XI, we show results that include only the BEPS measures of perceptions of the legal environment and also add country fixed effects to the equations. ${ }^{19}$ The legal coefficients are virtually unchanged when compared to the specifications without country effects (see Table IX). Thus, the significant impact of law perception on the lending decision of banks is caused by bank and not country variation. This suggests that it is not only the actual legal

\footnotetext{
${ }^{18}$ The regions are the EU countries, other former Soviet Union countries and Southern Eastern European countries.

${ }^{19} \mathrm{GDP}$ pc and inflation were removed from the specification for this estimation, since the variation of these variables is picked up by the country effects.
} 
system existing in a country (LTP measure) but also the individual banker's perception of these laws (BEPS measure) that matters for the lending decision of banks.

Finally, we want to test whether our findings only hold for the specific legal indicators utilized. From the LTP survey we also constructed a second legal indicator LTP - Quality of law (dum). In Table XII we show that results including this indicator are stronger than results with the LTP - Enforcement of law (dum) variable (see Table VIII, panel I). Here, also the LTP measure shows a positive correlation between a better legal environment and the proportion of SME lending. However, estimates with the LTP - Quality of law indicator as a sum variable (not shown) is somewhat weaker.

\section{Conclusion}

The legal environment does not only influence credit market development but also has an important impact on the customers banks lend to. The better the legal system the more willing a bank is to accept different types of assets as collateral and the more willing a bank is to lend to information opaque borrowers. On the contrary, the worse the legal environment the more a bank lends to customers that can either provide guarantees (government lending) or easily provide information about their projects (large enterprise lending). Thus, a better legal environment fosters private capital formation.

We find that a banker's willingness to accept collateral is associated with the quality of the legal system. When banks find themselves in a good institutional environment, they accept collateral as a security for lending contracts that involve a high degree of asymmetric information. If bankers have low perceptions of the quality of their environment they 
will not enter such contracts and rather channel their funds to large and government-owned enterprises. Finally, we find that not only the legal environment, but also the perception bankers have concerning the legal system matters for the allocation of bank lending. 


\section{A. Construction of LTP - Quality of law indicator}

In the following the underlying criteria of the LTP - Quality of law indicator are listed:

(i) Does the charge create a proprietary security right?

(ii) Can the charge be granted by any person?

(iii) Can the charge be granted to any person?

(iv) Can the charge secure any debt?

(v) Can the charge cover all types of asset?

(vi) Does the charge give priority over all other creditors?

For each of these criteria the EBRD assigns a score between 0 and 3, with zero meaning that a criteria is not fulfilled at all and 3 means a criteria is fully implemented. We sum up the scores of the six criteria, which yields us an indicators for the quality of the law related to secured transactions (LTP - Quality of law).

\section{B. Construction of BEPS perception indicators}

\section{- BEPS (im)movable assets perception}

Measures of perceptions of the banking environment were constructed from three other questions. The questionnaire included one question concerning a banker's perception towards laws related to movable assets and another question related to immovable assets. For both questions four statements were presented to which the responding bank executive indicated the extent of his or her agreement on a scale from 1 (strongly disagree) to 6 (strongly agree). These four statements are illustrated in the questionnaire excerpt shown below for the question concerning movable assets and are identical for the question relating to immovable assets. We added the scores (using averages for missing responses) in order to get an overall measure of respondents' confidence in the collateral laws. This yields our indicator BEPS - movable assets perception and BEPS - immovable assets perception.

BEPS Questionnaire: Question \#32

Q.32 Thinking of the laws on the books in your country in 2004 related to pledges (loans secured by movable assets), to what extent do you agree with the following statements?

a.) The laws provide adequate scope of security (e.g., types of assets received as collateral, types of debt that can be secured)

b.) The laws enable efficient creation and perfection of security rights (simple, cheap, fast)

c.) The laws enable efficient enforcement of security rights (simple, cheap, fast)

d.) The laws adequately protect secured creditor rights 


\section{- BEPS Court perception}

Finally, we use a question related to the ability of the court system to resolve business disputes. Respondents were asked to express their agreement with five statements on a scale from 1 (never) to 6 (always). These five statements are illustrated in the questionnaire excerpt II below.

BEPS Questionnaire: Question \#44

\begin{tabular}{|l|l|}
\hline Q.44 & $\begin{array}{l}\text { How often do you associate the following descriptions with the court system in resolving } \\
\text { business disputes? }\end{array}$ \\
\hline a.) Fair and impartial \\
\hline b.) Honest and uncorrupted \\
\hline c.) Quick and efficient \\
\hline d.) Affordable \\
\hline e.) Able to enforce its decisions \\
\hline
\end{tabular}

There are four dummy variables that measure the respondents' perceptions of the banking environment. A value of one indicates high degree of confidence in the collateral laws (movable and mortgage), the court system and the bank regulators. We added the scores of these five statements (using averages for missing responses) in order to get an overall measure of respondents' confidence in the court system (BEPS - Court perception). As described in the main test we also construct a 1/0 dummy variable in order to divide the survey into groups with high and low confidence in the court system (BEPS - Court perception [dum]). 


\section{References}

Akerlof, G. A., 1970. The market for 'lemons': Quality uncertainty and the market mechanism. The Quarterly Journal of Economics 84 (3), 488-500.

Bankscope, 2006. Internet database, Bureau van Dijk Electronic Publishing.

Berger, A. N., Klapper, L. F., Udell, G. F., 2001. The ability of banks to lend to informationally opaque small businesses. Journal of Banking \& Finance 25 (12), 2127-2167.

Berger, A. N., Udell, G. F., 1995. Relationship lending and lines of credit in small firm finance. Journal of Business 68 (3), 351-81.

Berger, A. N., Udell, G. F., 2002. Small business credit availability and relationship lending: The importance of bank organisational structure. Economic Journal 112 (477), F32-F53.

Besanko, D., Thakor, A. V., 1987. Collateral and rationing: Sorting equilibria in monopolistic and competitive credit markets. International Economic Review 28 (3), 671-89.

Bester, H., 1985. Screening vs. rationing in credit markets with imperfect information. American Economic Review 75 (4), 850-855.

Bonin, J. P., Hasan, I., Wachtel, P., 2005. Bank performance, efficiency and ownership in transition countries. Journal of Banking and Finance 29, 31-53.

Boot, A. W. A., Thakor, A. V., 1994. Moral hazard and secured lending in an infinitely repeated credit market game. International Economic Review 35 (4), 899-920.

Booth, L., Aivazian, V., Demirgüc-Kunt, A., Maksimovic, V., 02 2001. Capital structures in developing countries. Journal of Finance 56 (1), 87-130.

Braun, M., 2003. Financial contractibility and asset hardness. Working paper, Harvard University, Department of Economics.

Buch, C. M., 2003. Information or regulation: What drives the international activities of commercial banks? Journal of Money, Credit and Banking 35 (6), 851-869.

Davydenko, S. A., Franks, J. R., 2004. Do bankruptcy codes matter? A study of defaults in France, Germany, and the UK. Tech. rep.

Dell' Ariccia, G., Marquez, R., 2004. Information and bank credit allocation. Journal of Financial Economics 72 (1), 185-214.

Demirgüc-Kunt, A., Maksimovic, V., 1998. Law, finance and firm growth. Journal of Finance 53 (6), 2107-2137. 
Demirgüc-Kunt, A., Maksimovic, V., December 1999. Institutions, financial markets, and firm debt maturity. Journal of Financial Economics 54 (3), 295-336.

Djankov, S., Hart, O., McLiesh, C., Shleifer, A., 2006. Debt enforcement around the world. working paper, Harvard University.

Djankov, S., McLiesh, C., Shleifer, A., forthcoming. Private credit in 129 countries. Journal of Financial Economics 33 (3), 341-368.

Djankov, S., Porta, R. L., Lopez-De-Silanes, F., Shleifer, A., May 2003. Courts. The Quarterly Journal of Economics 118 (2), 453-517.

EBRD Legal Survey, 2004. Legal transition programme. Internet database, European Bank for Reconstruction and Development, http://www.ebrd.com/country/sector/law/index.html, accessed at 11th August, 2006.

Engle, R. F., Hendry, D. F., Richard, J.-F., March 1983. Exogeneity. Econometrica 51 (2), 277-304.

Fan, J. P., Titman, S., Twite, G., July 2006. An international comparison of capital structure and debt maturity choices. Working paper, University of Texas at Austin.

FitchRatings, 2006. Complete sovereign rating history. Fitch ratings ltd.

Giannetti, M., 2003. Do better institutions mitigate agency problems? evidence from corporate finance choices. Journal of Financial and Quantitative Analysis 38 (1), 185-212.

Giannetti, M., Ongena, S., 2005. Financial integration and entrepreneurial activity - Evidence from foreign bank entry in emerging markets. Working Paper Series 498, European Central Bank.

Hart, O., Moore, J., 1994. A theory of debt based on the inalienability of human capital. The Quarterly Journal of Economics 109 (4), 841-79.

Hart, O., Moore, J., February 1998. Default and renegotiation: A dynamic model of debt. The Quarterly Journal of Economics 113 (1), 1-41.

Haselmann, R. F. H., Vig, V., Pistor, K., 2006. How law affects lending. Working Paper 285, Columbia Law School.

Hoshi, T., 2006. Creditor rights and credit creation by banks in transition economies: Evidence from banking environment and performance survey. Working paper, University of California San Diego.

Jappelli, T., Pagano, M., October 2002. Information sharing, lending and defaults: Cross-country evidence. Journal of Banking \& Finance 26 (10), 2017-2045. 
La Porta, R., Lopez-de-Silanes, F., Shleifer, A., Vishny, R. W., 1997. Legal determinants of external finance. Journal of Finance 52, 1131-1150.

La Porta, R., Lopez-de-Silanes, F., Shleifer, A., Vishny, R. W., 1998. Law and finance. Journal of Political Economy 106 (6), 1113-1155.

Liberti, J., Mian, A., 2005. Uncovering collateral. Working paper, London Business School.

Menkhoff, L., Neuberger, D., Suwanaporn, C., January 2006. Collateral-based lending in emerging markets: Evidence from Thailand. Journal of Banking \& Finance 30 (1), 1-21.

Mian, A., 2006. Distance constraints: The limits of foreign lending in poor economies. Journal of Finance 61 (3), 1465-1505.

Pagano, M., Jappelli, T., December 1993. Information sharing in credit markets. Journal of Finance 48 (5), 1693-1718.

Pistor, K., 2000. Patterns of legal change: Shareholder and creditor rights in transition economies. European Business Organization Law Review 1, 59-108.

Qian, J., Strahan, P. E., 2005. How law and institutions shape financial contracts: The case of bank loans. Working Paper 11052, National Bureau of Economic Research, Inc.

Sengupta, R., forthcoming. Foreign entry and bank competition. Journal of Financial Economics.

Stiglitz, J., 2003. Globalization and Its Discontents. W. W. Norton \& Company, New York.

Vig, V., October 2006. Access to collateral and corporate debt structure: Evidence from a natural experiment. Working paper, Columbia Business School.

World Bank, 2006. World development indicators 2006. Interactive database, The World Bank.

World Bank, 2007. Doing business. Interactive database, World Bank Group - Private Sector Resources.

Zellner, A., 1962. An efficient method of estimating seemingly unrelated regressions and tests for aggregation bias. Journal of the American Statistical Association 57, 348-368. 
Table I

Definition and sources of variables

\begin{tabular}{|c|c|c|c|c|}
\hline Variable & Definition & Mean & St. Dev. & Source \\
\hline \multicolumn{5}{|c|}{ I. BEPS and LTP legal indicators } \\
\hline $\begin{array}{l}\text { Acceptance of } \\
\text { immovable assets }\end{array}$ & see Section 3.2 & 3.73 & 1.19 & BEPS survey \\
\hline $\begin{array}{l}\text { Acceptance of } \\
\text { movable assets }\end{array}$ & see Section 3.2 & 3.27 & 1.07 & BEPS survey \\
\hline $\begin{array}{l}\text { LTP - Enforcement of } \\
\text { law }\end{array}$ & see Section 3.3 & 19.54 & 6.61 & LTP survey \\
\hline $\begin{array}{l}\text { LTP - Quality of } \\
\text { law }\end{array}$ & see Appendix A & 15.07 & 1.54 & LTP survey \\
\hline $\begin{array}{l}\text { BEPS - Court } \\
\text { perception }\end{array}$ & see Appendix B & 16.96 & 4.58 & BEPS survey \\
\hline $\begin{array}{l}\text { BEPS - Perception of } \\
\text { immovable assets }\end{array}$ & see Appendix B & 15.16 & 3.98 & BEPS survey \\
\hline $\begin{array}{l}\text { BEPS - Perception of } \\
\text { movable assets }\end{array}$ & see Appendix B & 14.58 & 4.19 & BEPS survey \\
\hline \multicolumn{5}{|l|}{ II. Control variables } \\
\hline GOV & $\begin{array}{l}\text { value of one if bank is owned } \\
\text { by government (zero otherwise) }\end{array}$ & 0.08 & 0.28 & $\begin{array}{l}\text { BEPS survey/ } \\
\text { hand collected }\end{array}$ \\
\hline FOR & $\begin{array}{l}\text { value of one if bank is foreign } \\
\text { owned (zero otherwise) }\end{array}$ & 0.53 & 0.50 & $\begin{array}{l}\text { BEPS survey/ } \\
\text { hand collected }\end{array}$ \\
\hline $\mathrm{EU}$ & $\begin{array}{l}\text { value of one if bank is located } \\
\text { in a EU country (zero otherwise) }\end{array}$ & 0.34 & 0.47 & BEPS survey \\
\hline SEE & $\begin{array}{l}\text { value of one if bank is located } \\
\text { in a SEE country (zero otherwise) }\end{array}$ & 0.37 & 0.48 & BEPS survey \\
\hline $\log$ (Assets) & total assets & 13.13 & 1.59 & Bankscope (2006) \\
\hline GDP pc & GDP per capita in 1000s US\$ & 3.18 & 2.17 & World Bank (2006) \\
\hline Inflation & GDP price deflator in annual $\%$ & 9.22 & 6.60 & World Bank (2006) \\
\hline $\begin{array}{l}\text { Country risk } \\
\text { rating }\end{array}$ & $\begin{array}{l}\text { Fitch ratings on long-term government debt } \\
\text { (local currency) translated to numeric ranking }\end{array}$ & 10.86 & 3.20 & FitchRatings (2006) \\
\hline $\begin{array}{l}\text { Credit info } \\
\text { index }\end{array}$ & $\begin{array}{l}\text { index that measures rules affecting } \\
\text { the scope, access, and quality of credit information }\end{array}$ & 2.42 & 2.05 & World Bank (2007) \\
\hline Domestic credit & domestic credit as \% of GDP & 37.74 & 15.12 & World Bank (2006) \\
\hline GDP growth & GDP growth rate in annual \% & 6.93 & 2.07 & World Bank (2006) \\
\hline Interest spread & lending rate minus deposit rate & 5.86 & 2.53 & World Bank (2006) \\
\hline \multicolumn{5}{|l|}{ III. Instruments } \\
\hline Procedures & $\begin{array}{l}\text { number of procedures from moment plaintiff } \\
\text { files lawsuit until moment of payment }\end{array}$ & 30.74 & 6.81 & World Bank (2007) \\
\hline Time & calendar days to resolve the dispute & 449.20 & 287.14 & World Bank (2007) \\
\hline Cost & $\begin{array}{l}\text { cost in court fees and attorney fees as } \\
\text { percentage of debt value }\end{array}$ & 14.10 & 4.58 & World Bank (2007) \\
\hline Efficiency & measure of the efficiency of debt enforcement & 42.66 & 16.95 & Djankov et al. (2006) \\
\hline
\end{tabular}


Table II

Descriptive statistics of lending ratios

\begin{tabular}{|c|c|c|c|c|c|c|}
\hline & \multicolumn{2}{|c|}{ Enterprise lending } & \multicolumn{2}{|c|}{ Household lending } & \multirow{2}{*}{$\begin{array}{l}\text { Government } \\
\text { lending }\end{array}$} \\
\hline & & SME & large enter. & mortgage & consumer & \\
\hline \multicolumn{7}{|c|}{ I. Total } \\
\hline & mean & 40.51 & 19.32 & 8.80 & 16.17 & 5.61 \\
\hline & st dev & 27.72 & 21.93 & 15.55 & 19.17 & 11.89 \\
\hline & obs & 128 & 128 & 172 & 168 & 194 \\
\hline \multicolumn{7}{|c|}{ II. Ownership } \\
\hline & mean & 40.00 & 7.49 & 1.91 & 13.76 & 15.28 \\
\hline \multirow[t]{2}{*}{ gov } & st dev & 31.99 & 9.72 & 2.98 & 11.58 & 22.59 \\
\hline & obs & 11 & 11 & 15 & 14 & 16 \\
\hline \multirow{3}{*}{ dom } & mean & 48.24 & 23.55 & 6.10 & 13.43 & 3.28 \\
\hline & st dev & 25.75 & 25.51 & 12.38 & 15.17 & 6.89 \\
\hline & obs & 48 & 48 & 67 & 67 & 77 \\
\hline \multirow{3}{*}{ for } & mean & 35.22 & 18.26 & 11.96 & 18.66 & 5.85 \\
\hline & st dev & 27.49 & 19.95 & 18.06 & 22.45 & 11.87 \\
\hline & obs & 69 & 69 & 90 & 87 & 101 \\
\hline \multicolumn{7}{|c|}{ III.Region } \\
\hline & mean & 32.47 & 13.24 & 16.12 & 16.06 & 7.35 \\
\hline \multirow[t]{2}{*}{$\mathrm{EU}$} & st dev & 28.50 & 19.49 & 23.54 & 24.34 & 13.49 \\
\hline & obs & 35 & 35 & 59 & 56 & 64 \\
\hline \multirow{3}{*}{ SEE } & mean & 41.81 & 15.64 & 6.87 & 19.29 & 5.25 \\
\hline & st dev & 26.75 & 16.27 & 5.91 & 17.53 & 12.37 \\
\hline & obs & 55 & 55 & 65 & 65 & 71 \\
\hline \multirow{3}{*}{ FSU } & mean & 46.04 & 30.24 & 2.43 & 11.98 & 4.14 \\
\hline & st dev & 27.42 & 27.16 & 5.88 & 12.94 & 9.08 \\
\hline & obs & 38 & 38 & 48 & 47 & 59 \\
\hline \multicolumn{7}{|c|}{ IV. Size } \\
\hline \multirow{3}{*}{$<200$} & mean & 52.43 & 11.89 & 7.52 & 16.15 & 4.39 \\
\hline & st dev & 26.69 & 15.80 & 18.40 & 19.58 & 12.27 \\
\hline & obs & 41 & 41 & 53 & 53 & 57 \\
\hline \multirow{4}{*}{$\begin{array}{l}200- \\
1000\end{array}$} & mean & 39.65 & 20.18 & 7.06 & 17.63 & 4.41 \\
\hline & st dev & 28.29 & 22.30 & 10.18 & 22.29 & 10.96 \\
\hline & obs & 54 & 54 & 67 & 67 & 78 \\
\hline & mean & 27.60 & 28.02 & 11.60 & 15.16 & 7.52 \\
\hline \multirow[t]{2}{*}{$>1000$} & st dev & 21.67 & 25.56 & 13.30 & 13.58 & 11.81 \\
\hline & obs & 30 & 30 & 46 & 43 & 54 \\
\hline
\end{tabular}


Table III

\section{Correlations between different measures of legal environment}

LTP - Quality

of law

LTP - Enforcement

of law

BEPS - court

perception

BEPS - movable

assets perception

BEPS - immovable

assets perception

$\begin{array}{ccccc}\begin{array}{c}\text { LTP - Quality } \\ \text { of law } \\ 1\end{array} & \begin{array}{c}\text { LTP - Enforcement } \\ \text { of law }\end{array} & \begin{array}{c}\text { BEPS - Court } \\ \text { perception }\end{array} & \begin{array}{c}\text { BEPS - movable } \\ \text { assets perception }\end{array} & \begin{array}{c}\text { BEPS - immovable } \\ \text { assets perception }\end{array} \\ 0.40 & 1 & 1 & \\ -0.03 & 0.11 & 0.43 & 1 & 1 \\ 0.17 & 0.22 & 0.34 & 0.80 & \end{array}$


Table IV: Probit regression results

Notes: Coefficients of probit estimates of (1). Acceptance of collateral is a binary variable that takes the value of 1 if a bank has a high acceptance of (im)movable assets as collateral and 0 otherwise. Standard errors are reported in parentheses below each coefficient. Estimated are based on 171 observations. $* * *, * * *$ indicate significance at the 1,5,10\% level, respectively. In table columns labeled with ${ }^{*}$ the legal indicators is defined as a dummy variable. In all other columns the legal inidcators are included in their original form (the sum of all sub-criteria).

\begin{tabular}{|c|c|c|c|c|c|c|c|c|c|c|}
\hline & & Accepta & e of immov & le assets & & & Accept & ice of mova & e assets & \\
\hline & (1) & (2) & (3) & $(4)^{\#}$ & $(5)^{\#}$ & (6) & (7) & (8) & $(9)^{\#}$ & $(10)^{\#}$ \\
\hline const. & $\begin{array}{l}-1.601 \\
(1.02)\end{array}$ & $\begin{array}{l}-0.774 \\
(0.95)\end{array}$ & $\begin{array}{l}-1.538 \\
(0.96)\end{array}$ & $\begin{array}{l}-0.985 \\
(0.96)\end{array}$ & $\begin{array}{l}-0.580 \\
(0.93)\end{array}$ & $\begin{array}{c}-3.501 \\
(1.00)^{* * *}\end{array}$ & $\begin{array}{l}-1.740 \\
(0.94)^{*}\end{array}$ & $\begin{array}{c}-3.416 \\
(0.98) * * *\end{array}$ & $\begin{array}{l}-2.657 \\
(0.92)^{* * *}\end{array}$ & $\begin{array}{c}-2.372 \\
(0.89)^{* * *}\end{array}$ \\
\hline $\log$ (Assets) & $\begin{array}{c}0.163 \\
(0.07)^{* *}\end{array}$ & $\begin{array}{c}0.162 \\
(0.074)^{* *}\end{array}$ & $\begin{array}{c}0.170 \\
(0.07)^{* *}\end{array}$ & $\begin{array}{c}0.164 \\
(0.08)^{* *}\end{array}$ & $\begin{array}{l}0.166 \\
(0.07)^{* *}\end{array}$ & $\begin{array}{c}0.145 \\
(0.07)^{* *}\end{array}$ & $\begin{array}{c}0.130 \\
(0.07)^{*}\end{array}$ & $\begin{array}{c}0.144 \\
(0.07)^{* *}\end{array}$ & $\begin{array}{c}0.190 \\
(0.07)^{* * *}\end{array}$ & $\begin{array}{c}0.179 \\
(0.07)^{* * * *}\end{array}$ \\
\hline Foreign & $\begin{array}{c}-0.311 \\
(0.23)\end{array}$ & $\begin{array}{l}-0.350 \\
(0.23)\end{array}$ & $\begin{array}{l}-0.413 \\
(0.22)^{*}\end{array}$ & $\begin{array}{l}-0.407 \\
(0.24)^{*}\end{array}$ & $\begin{array}{l}-0.423 \\
(0.23)^{*}\end{array}$ & $\begin{array}{l}-0.130 \\
(0.23)\end{array}$ & $\begin{array}{l}-0.322 \\
(0.24)\end{array}$ & $\begin{array}{l}-0.127 \\
(0.23)\end{array}$ & $\begin{array}{l}-0.084 \\
(0.23)\end{array}$ & $\begin{array}{l}-0.163 \\
(0.22)\end{array}$ \\
\hline Government & $\begin{array}{c}-0.601 \\
(0.41)\end{array}$ & $\begin{array}{l}-0.736 \\
(0.39)^{*}\end{array}$ & $\begin{array}{l}-0.707 \\
(0.37)^{*}\end{array}$ & $\begin{array}{l}-0.663 \\
(0.40)^{*}\end{array}$ & $\begin{array}{c}-0.810 \\
(0.39)^{* *}\end{array}$ & $\begin{array}{l}-0.286 \\
(0.39)\end{array}$ & $\begin{array}{c}-0.191 \\
(0.41)\end{array}$ & $\begin{array}{l}-0.290 \\
(0.39)\end{array}$ & $\begin{array}{l}-0.305 \\
(0.38)\end{array}$ & $\begin{array}{l}-0.397 \\
(0.37)\end{array}$ \\
\hline GDP pc & $\begin{array}{c}-0.193 \\
(0.06)^{* * * *}\end{array}$ & $\begin{array}{c}-0.194 \\
(0.06)^{* * * *}\end{array}$ & $\begin{array}{c}-0.143 \\
(0.06)^{* * *}\end{array}$ & $\begin{array}{l}-0.184 \\
(0.06)^{* * *}\end{array}$ & $\begin{array}{c}-0.182 \\
(0.06)^{* * * *}\end{array}$ & $\begin{array}{c}-0.133 \\
(0.06)^{* *}\end{array}$ & $\begin{array}{c}-0.161 \\
(0.07)^{* *}\end{array}$ & $\begin{array}{l}-0.139 \\
(0.06) * *\end{array}$ & $\begin{array}{l}-0.138 \\
(0.07)^{* *}\end{array}$ & $\begin{array}{c}-0.142 \\
(0.07)^{* *}\end{array}$ \\
\hline Inflation & $\begin{array}{c}-0.079 \\
(0.02)^{* * *}\end{array}$ & $\begin{array}{c}-0.084 \\
(0.02)^{* * * *}\end{array}$ & $\begin{array}{c}-0.077 \\
(0.02)^{* * *}\end{array}$ & $\begin{array}{c}-0.080 \\
(0.02)^{* * * *}\end{array}$ & $\begin{array}{c}-0.085 \\
(0.02)^{* * * *}\end{array}$ & $\begin{array}{c}0.065 \\
(0.02)^{* * * *}\end{array}$ & $\begin{array}{c}0.052 \\
(0.02)^{* * * *}\end{array}$ & $\begin{array}{c}0.065 \\
(0.02)^{* * * *}\end{array}$ & $\begin{array}{c}0.067 \\
(0.02)^{* * * *}\end{array}$ & $\begin{array}{c}0.066 \\
(0.02) * * *\end{array}$ \\
\hline $\begin{array}{l}\text { BEPS - (im)movable } \\
\text { asset perception }\end{array}$ & $\begin{array}{c}0.056 \\
(0.03)^{* *}\end{array}$ & - & $\begin{array}{c}0.062 \\
(0.02)^{* * *}\end{array}$ & $\begin{array}{c}0.592 \\
(0.21)^{* * *}\end{array}$ & - & $\begin{array}{c}0.103 \\
(0.03)^{* * *}\end{array}$ & - & $\begin{array}{c}0.105 \\
(0.03) * * *\end{array}$ & $\begin{array}{c}0.589 \\
(0.25)^{* *}\end{array}$ & - \\
\hline $\begin{array}{l}\text { LTP - Enforcement } \\
\text { of law }\end{array}$ & $\begin{array}{l}0.019 \\
(0.02)\end{array}$ & $\begin{array}{c}0.028 \\
(0.02)^{*}\end{array}$ & - & $\begin{array}{c}0.441 \\
(0.23)^{* *}\end{array}$ & $\begin{array}{c}0.498 \\
(0.22)^{* *}\end{array}$ & $\begin{array}{l}0.007 \\
(0.02)\end{array}$ & $\begin{array}{l}0.023 \\
(0.01)\end{array}$ & - & $\begin{array}{l}0.358 \\
(0.28)\end{array}$ & $\begin{array}{c}0.458 \\
(0.27)^{*}\end{array}$ \\
\hline LR statistic & 31.21 & 27.73 & 30.58 & 36.06 & 28.73 & 50.17 & 34.67 & 50.00 & 41.60 & 36.16 \\
\hline
\end{tabular}




\section{Table V \\ Examples illustrating the interpretation of probit coefficients}

Notes: This table reports implied probabilities of a domestic bank with mean asset size accepting collateral conditional on different legal settings based on estimates in Table IV, (4) and (9).

Probability of accepting immovable assets as collateral

\begin{tabular}{lccc} 
& & \multicolumn{2}{c}{ LTP - Quality of law } \\
& & poor & good \\
BEPS - immovable & low & $44.43 \%$ & $61.79 \%$ \\
assets perception & high & $67.36 \%$ & $81.33 \%$
\end{tabular}

Probability of accepting movable assets as collateral

\begin{tabular}{lccc} 
& & \multicolumn{2}{c}{ LTP - Quality of law } \\
& & poor & good \\
BEPS - movable & low & $49.60 \%$ & $63.68 \%$ \\
assets perception & high & $71.90 \%$ & $82.64 \%$
\end{tabular}




\section{Table VI}

\section{SUR estimates for loan portfolio decision - sum indicators}

Notes: SUR estimates for system (3). Standard errors are reported in parentheses. The regressions were run for 219 banks for the year 2004. The bottom line of the table states the adjusted R-squared of each estimation. $* * *, * * * *$ indicate significance at the $1,5,10 \%$ level, respectively.

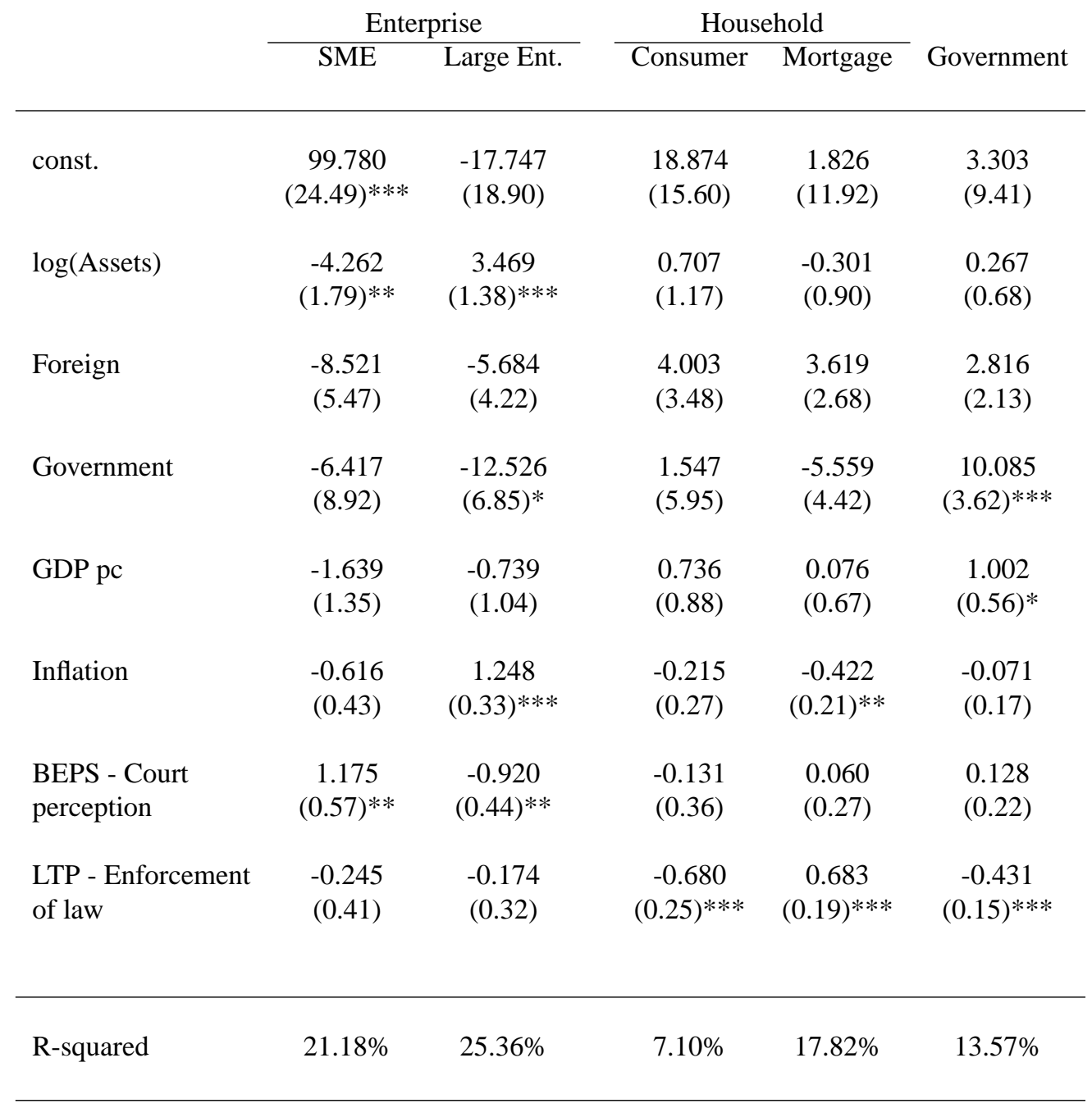




\section{Table VII \\ IV estimates for loan portfolio decision - sum indicators}

Notes: Regression results for system (3) with two-stage-least-squares. The instruments used are: efficiency of debt enforcement, average days it takes to collect defaulted debt, number of procedures necessary to collect defaulted debt as well as the other independent variables. Standard errors are reported in parentheses. The regressions were run for 219 banks for the year 2004. The bottom line of the table states the adjusted Rsquared of each estimation.***,**,* indicate significance at the $1,5,10 \%$ level, respectively.

\begin{tabular}{|c|c|c|c|c|c|}
\hline & \multicolumn{2}{|c|}{ Enterprise } & \multicolumn{2}{|c|}{ Household } & \multirow[b]{2}{*}{ Governmen } \\
\hline & SME & Large Ent. & Consumer & Mortgage & \\
\hline const. & $\begin{array}{c}57.969 \\
(41.098)\end{array}$ & $\begin{array}{c}0.277 \\
(2.133)\end{array}$ & $\begin{array}{c}42.870 \\
(26.931)\end{array}$ & $\begin{array}{l}-7.357 \\
(21.140)\end{array}$ & $\begin{array}{c}9.632 \\
(18.051)\end{array}$ \\
\hline $\log$ (Assets) & $\begin{array}{c}-4.539 \\
(2.415)^{*}\end{array}$ & $\begin{array}{c}4.646 \\
(1.993)^{* *}\end{array}$ & $\begin{array}{c}0.534 \\
(1.283)\end{array}$ & $\begin{array}{l}-0.674 \\
(1.635)\end{array}$ & $\begin{array}{c}0.083 \\
(0.786)\end{array}$ \\
\hline Foreign & $\begin{array}{l}-6.707 \\
(7.197)\end{array}$ & $\begin{array}{c}-9.646 \\
(5.388)^{*}\end{array}$ & $\begin{array}{l}2.636 \\
(4.132)\end{array}$ & $\begin{array}{c}4.336 \\
(4.336)\end{array}$ & $\begin{array}{c}4.065 \\
(2.356)^{*}\end{array}$ \\
\hline Government & $\begin{array}{c}-7.064 \\
(13.393)\end{array}$ & $\begin{array}{l}-12.175 \\
(6.727)^{*}\end{array}$ & $\begin{array}{c}0.752 \\
(6.127)\end{array}$ & $\begin{array}{c}-7.993 \\
(4.078)^{* *}\end{array}$ & $\begin{array}{l}11.281 \\
(6.821)^{*}\end{array}$ \\
\hline GDP & $\begin{array}{l}-1.936 \\
(1.457)\end{array}$ & $\begin{array}{c}1.253 \\
(1.054)\end{array}$ & $\begin{array}{c}0.673 \\
(0.924)\end{array}$ & $\begin{array}{l}-0.483 \\
(0.570)\end{array}$ & $\begin{array}{c}1.101 \\
(0.725)\end{array}$ \\
\hline Inflation & $\begin{array}{l}-0.545 \\
(0.458)\end{array}$ & $\begin{array}{c}1.405 \\
(0.363)^{* * *}\end{array}$ & $\begin{array}{l}-0.250 \\
(0.267)\end{array}$ & $\begin{array}{c}-0.454 \\
(0.234)^{*}\end{array}$ & $\begin{array}{l}-0.045 \\
(0.213)\end{array}$ \\
\hline $\begin{array}{l}\text { BEPS - Perception } \\
\text { of law }\end{array}$ & $\begin{array}{c}3.518 \\
(1.681)^{* *}\end{array}$ & $\begin{array}{c}-2.939 \\
(0.995)^{* * *}\end{array}$ & $\begin{array}{l}-1.277 \\
(1.199)\end{array}$ & $\begin{array}{c}1.041 \\
(0.688)\end{array}$ & $\begin{array}{l}-0.165 \\
(0.792)\end{array}$ \\
\hline $\begin{array}{l}\text { LTP - Enforcement } \\
\text { of law }\end{array}$ & $\begin{array}{l}-0.117 \\
(0.488)\end{array}$ & $\begin{array}{l}-0.132 \\
(0.298)\end{array}$ & $\begin{array}{c}-0.664 \\
(0.297)^{* *}\end{array}$ & $\begin{array}{c}0.638 \\
(0.257)^{* * *}\end{array}$ & $\begin{array}{c}-0.426 \\
(0.193)^{* *}\end{array}$ \\
\hline R-squared & $13.60 \%$ & $31.75 \%$ & $3.89 \%$ & $11.85 \%$ & $12.19 \%$ \\
\hline
\end{tabular}




\section{Table VIII \\ Regression results for loan portfolio decision - dummy legal indicators}

Notes: Regression results for system (3). For the IV estimates in panel II the following instruments are used: interest spread, domestic credit and GDP growth as well as the other independent variables. Standard errors are reported in parentheses. The regressions were run for 219 banks for the year 2004. The bottom line of the table states the adjusted R-squared of each estimation. ***,*** indicate significance at the 1, 5, $10 \%$ level, respectively.

\begin{tabular}{|c|c|c|c|c|c|}
\hline & \multicolumn{2}{|c|}{ Enterprise } & \multicolumn{2}{|c|}{ Household } & \multirow[b]{2}{*}{ Governmen } \\
\hline & SME & Large Ent. & Consumer & Mortgage & \\
\hline \multicolumn{6}{|l|}{ I. SUR estimates } \\
\hline $\begin{array}{l}\text { BEPS - Perception } \\
\text { of law (dum) }\end{array}$ & $\begin{array}{c}17.783 \\
(5.17)^{* * *}\end{array}$ & $\begin{array}{c}-12.690 \\
(4.01)^{* * *}\end{array}$ & $\begin{array}{l}-1.762 \\
(3.20)\end{array}$ & $\begin{array}{l}-1.104 \\
(2.28)\end{array}$ & $\begin{array}{l}1.629 \\
(1.90)\end{array}$ \\
\hline $\begin{array}{l}\text { LTP - Enforcement } \\
\text { of law (dum) }\end{array}$ & $\begin{array}{l}1.981 \\
(4.89)\end{array}$ & $\begin{array}{c}-8.619 \\
(4.41)^{* *}\end{array}$ & $\begin{array}{c}-12.853 \\
(3.73)^{* * *}\end{array}$ & $\begin{array}{c}14.247 \\
(2.73)^{* * *}\end{array}$ & $\begin{array}{c}-4.759 \\
(1.84)^{* * *}\end{array}$ \\
\hline R-squared & $25.75 \%$ & $28.47 \%$ & $7.06 \%$ & $24.90 \%$ & $12.86 \%$ \\
\hline \multicolumn{6}{|c|}{ II. Instrumental variable estimates } \\
\hline $\begin{array}{l}\text { BEPS - Perception } \\
\text { of law (dum) }\end{array}$ & $\begin{array}{c}34.676 \\
(18.28)^{*}\end{array}$ & $\begin{array}{c}-26.359 \\
(12.27)^{* *}\end{array}$ & $\begin{array}{l}-23.793 \\
(13.35)^{*}\end{array}$ & $\begin{array}{l}2.343 \\
(9.27)\end{array}$ & $\begin{array}{r}-1.394 \\
(8.69)\end{array}$ \\
\hline $\begin{array}{l}\text { LTP - Enforcement } \\
\text { of law (dum) }\end{array}$ & $\begin{array}{l}2.056 \\
(7.68)\end{array}$ & $\begin{array}{l}-3.139 \\
(4.33)\end{array}$ & $\begin{array}{l}-7.467 \\
(4.41)^{*}\end{array}$ & $\begin{array}{c}14.357 \\
(4.88)^{* * *}\end{array}$ & $\begin{array}{c}-5.422 \\
(2.83)^{* *}\end{array}$ \\
\hline R-squared & $24.00 \%$ & $36.58 \%$ & $1.19 \%$ & $24.47 \%$ & $10.09 \%$ \\
\hline
\end{tabular}




\section{Table IX}

\section{SUR estimates for loan portfolio decision - including LTP and BEPS indicators separately}

Notes: SUR estimates for system (3). Standard errors are reported in parentheses. The regressions were run for 219 banks for the year 2004. The bottom line of the table states the adjusted R-squared of each estimation. $* * *, * * *$ indicate significance at the $1,5,10 \%$ level, respectively.

\begin{tabular}{|c|c|c|c|c|c|}
\hline & \multicolumn{2}{|c|}{ Enterprise } & \multicolumn{2}{|c|}{ Household } & \multirow[b]{2}{*}{ Government } \\
\hline & SME & Large Ent. & Consumer & Mortgage & \\
\hline $\begin{array}{l}\text { LTP - Enforcement } \\
\text { of law }\end{array}$ & $\begin{array}{l}-0.199 \\
(0.37)\end{array}$ & $\begin{array}{l}-0.614 \\
(0.40)\end{array}$ & $\begin{array}{c}-0.493 \\
(0.24)^{* *}\end{array}$ & $\begin{array}{c}0.528 \\
(0.17)^{* * *}\end{array}$ & $\begin{array}{c}-0.369 \\
(0.13) * * *\end{array}$ \\
\hline R-squared & $19.20 \%$ & $23.22 \%$ & $4.85 \%$ & $15.08 \%$ & $13.97 \%$ \\
\hline $\begin{array}{l}\text { BEPS - Court } \\
\text { perception }\end{array}$ & $\begin{array}{c}1.181 \\
(0.57)^{* *}\end{array}$ & $\begin{array}{c}-0.923 \\
(0.43) * *\end{array}$ & $\begin{array}{l}-0.146 \\
(0.37)\end{array}$ & $\begin{array}{l}0.103 \\
(0.28)\end{array}$ & $\begin{array}{l}0.106 \\
(0.23)\end{array}$ \\
\hline R-squared & $21.14 \%$ & $25.10 \%$ & $2.23 \%$ & $10.36 \%$ & $8.92 \%$ \\
\hline $\begin{array}{l}\text { LTP - Enforcement } \\
\text { of law (dum) }\end{array}$ & $\begin{array}{l}0.054 \\
(4.73)\end{array}$ & $\begin{array}{c}-9.667 \\
(4.22)^{* * *}\end{array}$ & $\begin{array}{c}-9.197 \\
(3.70) * * *\end{array}$ & $\begin{array}{c}11.633 \\
(2.59)^{* * *}\end{array}$ & $\begin{array}{c}-4.025 \\
(1.71)^{* *}\end{array}$ \\
\hline R-squared & $19.26 \%$ & $25.86 \%$ & $4.77 \%$ & $20.34 \%$ & $12.04 \%$ \\
\hline $\begin{array}{l}\text { BEPS - Court } \\
\text { perception (dum) }\end{array}$ & $\begin{array}{c}17.926 \\
(5.15)^{* * *}\end{array}$ & $\begin{array}{c}-13.322 \\
(4.02)^{* * *}\end{array}$ & $\begin{array}{l}-2.350 \\
(3.31)\end{array}$ & $\begin{array}{l}-0.339 \\
(2.46)\end{array}$ & $\begin{array}{l}1.520 \\
(1.93)\end{array}$ \\
\hline R-squared & $25.91 \%$ & $27.61 \%$ & $2.30 \%$ & $10.66 \%$ & $10.59 \%$ \\
\hline
\end{tabular}


Table X

SUR estimates for loan portfolio decision - controlling for regional and country effects (sum indicators)

Notes: SUR estimates for system (3). Standard errors are reported in parentheses. The regressions were run for 219 banks for the year 2004. The bottom line of the table states the adjusted R-squared of each estimation. $* * *, * *, *$ indicate significance at the $1,5,10 \%$ level, respectively.

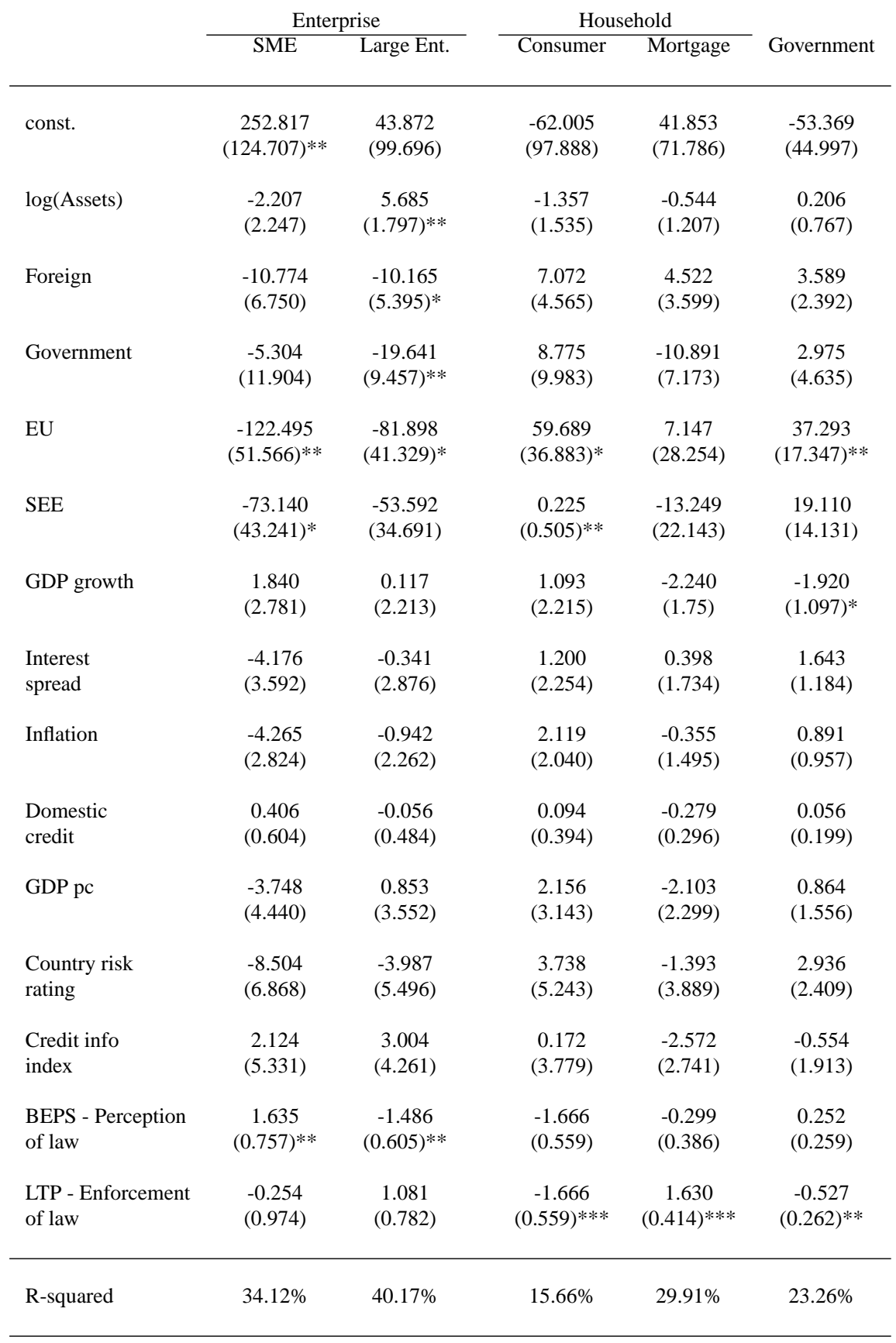




\section{Table XI}

SUR estimates for loan portfolio decision with for country fixed effects

Notes: SUR estimates for estimating (3). Standard errors are reported in parentheses. The regressions were run for 219 banks for the year 2004. The bottom line of the table states the adjusted R-squared of each estimation. $* * *, * *, *$ indicate significance at the $1,5,10 \%$ level, respectively.

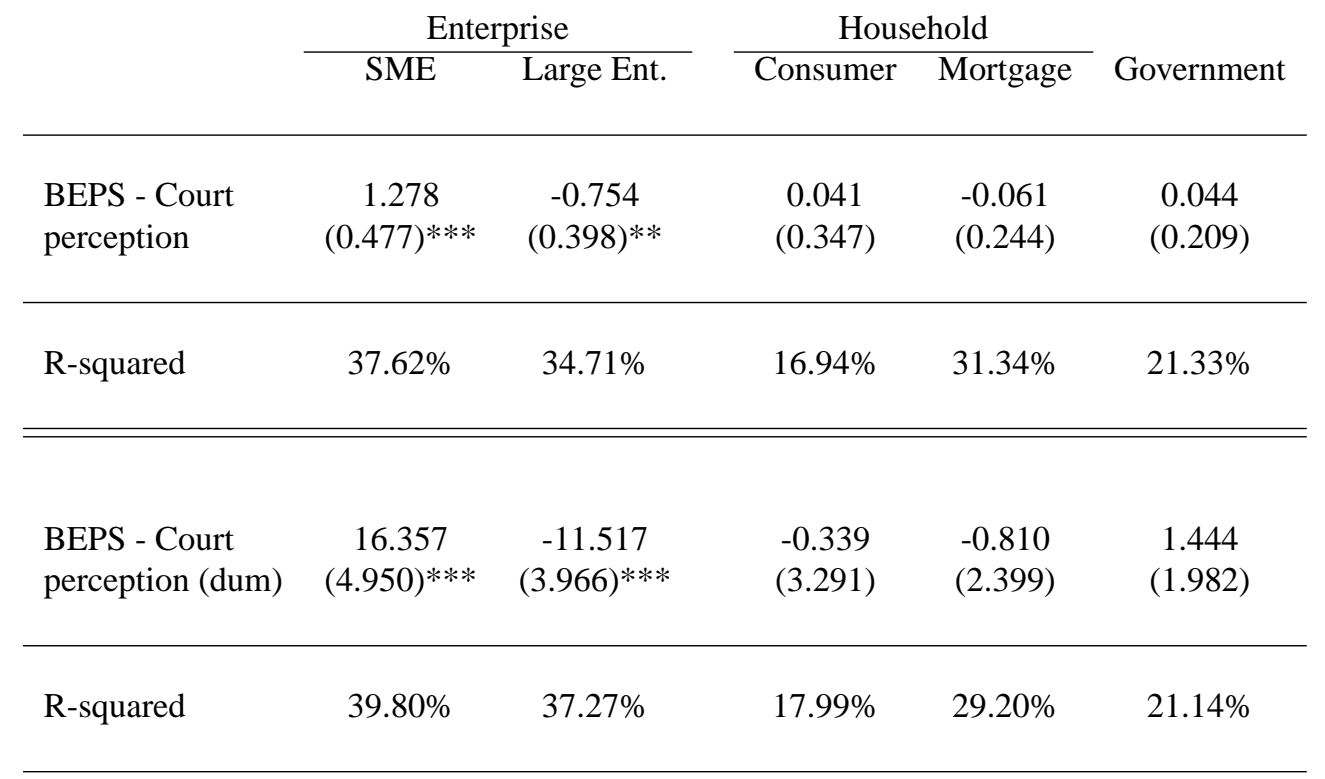




\section{Table XII}

\section{SUR estimates for loan portfolio decision - LTP Quality of Law (dum)}

Notes: SUR estimates for system (3). Standard errors are reported in parentheses. The regressions were run for 219 banks for the year 2004. The bottom line of the table states the adjusted R-squared of each estimation. $* * *, * *, *$ indicate significance at the $1,5,10 \%$ level, respectively.

\begin{tabular}{|c|c|c|c|c|c|}
\hline & \multicolumn{2}{|c|}{ Enterprise } & \multicolumn{2}{|c|}{ Household } & \multirow[b]{2}{*}{ Government } \\
\hline & SME & Large Ent. & Consumer & Mortgage & \\
\hline const. & $\begin{array}{c}105.914 \\
(20.84)^{* * *}\end{array}$ & $\begin{array}{l}-32.923 \\
(19.34)^{*}\end{array}$ & $\begin{array}{l}17.374 \\
(14.75)\end{array}$ & $\begin{array}{c}2.724 \\
(11.26)\end{array}$ & $\begin{array}{l}3.971 \\
(8.68)\end{array}$ \\
\hline $\log$ (Assets) & $\begin{array}{c}-4.852 \\
(1.68)^{* * * *}\end{array}$ & $\begin{array}{c}4.825 \\
(1.41)^{* * *}\end{array}$ & $\begin{array}{l}0.420 \\
(1.15)\end{array}$ & $\begin{array}{l}0.017 \\
(0.88)\end{array}$ & $\begin{array}{l}0.147 \\
(0.66)\end{array}$ \\
\hline Foreign & $\begin{array}{l}-10.874 \\
(5.17)^{* *}\end{array}$ & $\begin{array}{l}-7.721 \\
(4.12)^{*}\end{array}$ & $\begin{array}{c}5.709 \\
(3.48)^{*}\end{array}$ & $\begin{array}{l}2.810 \\
(2.66)\end{array}$ & $\begin{array}{l}3.689 \\
(2.11)^{*}\end{array}$ \\
\hline Government & $\begin{array}{l}-6.365 \\
(8.33)\end{array}$ & $\begin{array}{l}-15.820 \\
(7.31)^{* *}\end{array}$ & $\begin{array}{l}0.651 \\
(5.98)\end{array}$ & $\begin{array}{l}-4.828 \\
(4.41)\end{array}$ & $\begin{array}{c}9.982 \\
(3.58)^{* * * *}\end{array}$ \\
\hline GDP pc & $\begin{array}{l}-1.844 \\
(1.22)\end{array}$ & $\begin{array}{l}0.123 \\
(1.13)\end{array}$ & $\begin{array}{l}-0.672 \\
(0.865)\end{array}$ & $\begin{array}{c}1.442 \\
(0.663)^{* *}\end{array}$ & $\begin{array}{l}-0.030 \\
(0.542)\end{array}$ \\
\hline Inflation & $\begin{array}{l}-0.347 \\
(0.41)\end{array}$ & $\begin{array}{c}1.418 \\
(0.62)^{* *}\end{array}$ & $\begin{array}{l}-0.413 \\
(0.28)\end{array}$ & $\begin{array}{l}-0.177 \\
(0.21)\end{array}$ & $\begin{array}{l}-0.246 \\
(0.17)\end{array}$ \\
\hline $\begin{array}{l}\text { BEPS - Court } \\
\text { perception (dum) }\end{array}$ & $\begin{array}{c}20.579 \\
(5.42)^{* * *}\end{array}$ & $\begin{array}{c}-14.634 \\
(4.64)^{* * *}\end{array}$ & $\begin{array}{r}-1.083 \\
(3.54)\end{array}$ & $\begin{array}{l}-1.866 \\
(2.65)\end{array}$ & $\begin{array}{l}2.677 \\
(2.09)\end{array}$ \\
\hline $\begin{array}{l}\text { LTP - Quality } \\
\text { of law (dum) }\end{array}$ & $\begin{array}{l}11.748 \\
(7.02)^{*}\end{array}$ & $\begin{array}{c}-9.058 \\
(4.27)^{* *}\end{array}$ & $\begin{array}{c}-8.617 \\
(3.46)^{* * *}\end{array}$ & $\begin{array}{c}7.807 \\
(2.59)^{* *}\end{array}$ & $\begin{array}{c}-6.257 \\
(2.09)^{* * *}\end{array}$ \\
\hline R-squared & $28.71 \%$ & $30.53 \%$ & $6.74 \%$ & $15.29 \%$ & $13.87 \%$ \\
\hline
\end{tabular}

